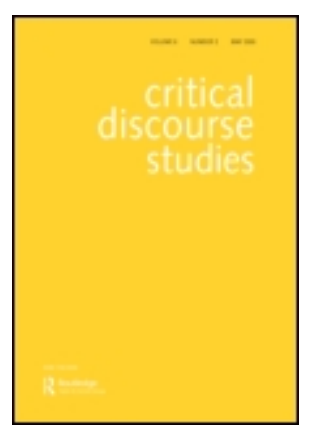

\title{
Rethinking Intertextuality in CDA
}

\begin{tabular}{|r|l|}
\hline Journal: & Critical Discourse Studies \\
\hline Manuscript ID & RCDS-2019-0034 \\
\hline Manuscript Type: & Full Length Article \\
\hline Keywords: & Intertextuality, Discourse, Orders of discourse \\
\hline \multicolumn{2}{|l}{} \\
\end{tabular}

\section{SCHOLARONE ${ }^{\text {M }}$ Manuscripts}

This is an Accepted Manuscript of an article published by Taylor \& Francis in Critical Discourse Studies on 24 April 2019, available online: https://www.tandfonline.com/doi/full/10.1080/17405904.2019.1609538. 


\section{Rethinking Intertextuality in CDA}

Intertextuality - instances of texts linking to other texts (explicitly, implicitly, by referring to them or incorporating elements of them) - is a key concept with which CDA accounts for discursive elements in social relations of power and solidarity. However, 'intertextuality' has not been widely operationalised to chart existing relations of power and solidarity at the levels of discourse and orders of discourse. This article develops the methodological framework for intertextuality in CDA and makes that framework more congruent with its potential to analyse and critique social relations of power and solidarity through intertextuality than has been the case until now. It introduces three concepts: the inter-text, networks of inter-texts and typicality. It discusses two methodological options for creating a corpus for analysing networks of inter-texts and presents new analytical categories which recognise intertextual reference to whole texts. Crucially, it emphasises absence and ambiguity as key analytical foci for intertextuality.

Keywords: intertextuality; discourse; orders of discourse

\section{Introduction}

Intertextuality - instances of texts linking to other texts (explicitly, implicitly, by referring to them or incorporating elements of them) - is a key concept with which CDA accounts for discursive elements in social relations of power and solidarity. When patterns of intertextuality become repeated, habitual, or conventional, they form a type of discursive relation between aspects of social formations and practices. Intertextuality operates at all levels of language-use and can be observed in:

(1) texts - actual pieces of language produced in the process of events,

(2) discourse - conventional or habitual language patterns associated with social practices, and

(3) orders of discourse - the discursive aspect of networks of social practices

For example, texts refer to some other texts and not others; to some favourably and 
others less so. At the level of discourse, social practices have patterns of intertextuality whereby some text-types, sources of text or even specific texts are typically referred to whilst others are not, and, again some are typically framed favourably, others not. Similarly, these patterns occur at the level of orders of discourse in networks of social practice. None of these patterns of intertextuality is likely to be inevitable or necessary and each pattern constitutes a tendency which contributes to relations of power and solidarity within and between events and social practices.

However, 'intertextuality' has not been widely operationalised to chart existing relations of power and solidarity at the levels of discourse and orders of discourse; rather, applications of intertextuality in the CDA literature tend to analyse texts only as parts of specific events. In this journal, for example, a search of the web pages for 'intertextuality' returns 48 'hits' from volumes 1-15. Yet only 5 give 'intertextuality' as a keyword: Jung-Wook Hong (2012), analyses the 2008 Mcdonald's Corporate Social Responsibility report; Oostendorp (2014), shows how intertextuality contributes to an identity construct of Jacob Zuma; Salama (2012) shows how Obama's Cairo speech drew widely on texts for rhetorical appeal; and Lasson (2008) presents a set of textual features which can indicate intertextual reference within texts. Only Bubikova-Moan (2017), refers directly to intertextuality in social practice: Norwegian language education policy. CDA has not, generally, told us about intertextual tendencies at the level of discourse and orders of discourse; we do not know whether the findings above are typical for their practice, or network of practices, or anomalous and unique to the context under investigation.

This article sets out a first step toward an enhanced theoretical and methodological understanding of intertextuality in CDA. To do so, in this article, I focus primarily on one form of intertextuality: manifest intertextuality (see below for 
discussion). I argue that we can enhance CDA's capacity to critically analyse discourse and orders of discourse by rethinking our analytical framework for intertextuality. To do this, I show, in section 2, how Kristeva's (1986) original conceptualisation of intertextuality was highly ambiguous and underdeveloped for the purposes of text and discourse analysis; in section 3, I show how Fairclough's (1992, 2003) accounts had come to disambiguate elements of intertextuality but carried over some the original ambiguity - meaning that the analytical framework for intertextuality has remained incongruent with the potential for intertextual analysis of discourse and orders of discourse. In section 4, I present the heart of the argument: that to facilitate analysis of intertextuality that goes beyond the level of the text we need to take the process of disambiguation further so that we can better apply intertextual analysis to discourse and orders of discourse. I use the example of a press release from the UK's former Department of Energy and Climate change, and a speech to which it refers given by a former Secretary of State for that department, Amber Rudd. In section 5, I present concepts for disambiguating intertextuality at these levels: the 'inter-text', the network of inter-texts, networks of social formations and practices, and 'typicality'. I go on to discuss two methodological options for creating a corpus for analysing networks of inter-texts and present additional analytical categories which recognise intertextual reference to whole texts. Crucially, I emphasise absence and ambiguity as key analytical foci for intertextuality. I conclude that this article develops and further disambiguates the methodological framework for intertextuality - specifically manifest intertextuality in CDA and makes that framework more congruent with potential to analyse and critique social relations of power and solidarity through intertextuality than has been the case until now. 


\section{Origins of Intertextuality: Insight and Ambiguity}

Kristeva's original conceptualisation of intertextuality, which she developed in relation to literary texts and in dialogue with the work of Bakhtin, is highly ambiguous in terms of whether we should understand 'intertextuality' as reference to specific other texts, or to a more general response and interaction with a body of literature. On one hand, Kristeva appears to conceive intertextuality as a one-to-one relationship between individual texts which is manifest through 'quotation': 'any text is constructed as a mosaic of quotations; any text is the absorption and transformation of another' (Kristeva, 1986, p. 37). On the other hand, she conceives intertextuality as a relation both between two individual texts and as a relation between the act of writing and an amorphous body of previous literature: 'Bakhtin considers writing as a reading of the anterior literary corpus and the text as an absorption of and a reply to another text' (Kristeva, 1986, p. 39). Indeed, Kristeva saw a lack of distinction in the work of Bakhtin as advantageous 'what appears as a lack of rigour is in fact an insight first introduced into literary theory by Bakhtin' (Kristeva, 1986, p. 37). Indeed, this blurring of boundaries is likely to have been useful for Kristeva in developing her relational view of literature: 'a model where literary structure does not simply exist but is generated in relation to another structure' (Kristeva, 1986, p. 35). For critical discourse analysts, and others who sought to operationalise intertextuality as an analytical tool in social science, this ambiguity is a disadvantage.

The original conceptualisation brought with it problems which we can now resolve. These problems arise from the underdevelopment, in Kristeva, of three aspects of intertextuality. First, when referring to what we now call manifest intertextuality, Kristeva refers to 'quotation' and 'mosaics of quotations'. This gives a limited conception of how intertextual reference can be manifest in referring texts. Intertextuality, as I show below, can appear not just though quotes but, for example, 
through naming a text: “"At the Coal Face” by Nicholas Evans'. For me, the manifestation of intertextuality is better conceived more broadly: it can refer to a text as a whole. As I show in the section 3, below, CDA has retained an emphasis on 'quotation' in analysing intertextuality which has limited its analytical purview.

Second, Kristeva's conception of intertextuality appears to retain a focus on the text that is referring to other texts: the implication is that intertextuality is mostly a matter of the effect of other texts on the text under examination. Despite using the phrase 'mosaic of quotations' the interest is on the result of that mosaic in the text and not on the sources of that 'mosaic' and the network of social practices that provide them. Moreover, Kristeva returns to a formulation which shows intertextuality as a relation between a single text and another single text: 'any text is the absorption and transformation of another' (Kristeva, 1986, p. 37). What we ought to focus upon in CDA, though, are the multiple sources of texts that tend to be 'absorbed' into others; we ought to be able to tell when intertextuality is subject to powerful influences over which texts become 'absorbed' and, thereby, chart social hierarchy and distance via intertextual analysis. In the example I give below, the minister refers to texts from industry, science, and politics when presenting a new energy policy but does not refer to texts from advocates of the environment, of public health or of common ownership of energy production. From a single text we cannot be certain that this pattern is indicative of UK politics but a broader and more systematic analysis of such texts could. CDA's later adoption of the concept of 'orders of discourse' opens a way of thinking about intertextuality as operating at the discursive level and being a tendency of social practice and networks of practice. However, I shall also argue, below, that CDA's analytical concepts for charting and analysing intertextuality as an element of discourse and orders of discourse are not well developed. 
Third, Kristeva's work on intertextuality emphasises the presence of intertextual reference but misses the potential importance of the absence of intertextual reference. CDA consistently shows that absences (what is not said, or acknowledged) in the patterns of discourse can be significant. However, this insight has not, until now, been emphasised in the analysis of intertextuality. In my view, this is in part a legacy of Kristeva's focus on presence and a legacy of maintaining an analytical focus at the level of texts. If we shift our focus of analysis to the level of the discursive and orders of discourses, and if we consider intertextuality as a means of linking and exploiting various aspects of these practices, the significance of 'absence' at all levels is apparent. I shall demonstrate below that identification of absences is crucial to a critical analysis of intertextuality in charting discourse and orders of discourse.

\section{Disambiguating Intertextuality in CDA}

After Kristeva, work on intertextuality - particularly in the fields of language and discourse analysis - began to disambiguate intertextuality. Fairclough, for example, set out to 'make the concept of intertextuality somewhat more concrete by using it to analyse texts' and to 'set out rather more systematically the potential of the concept for discourse analysis' (Fairclough, 1992, p. 101). Analysis of intertextuality was seen to have the potential to chart power relations and processes of social change within and between societal formations and practices:

\footnotetext{
Not only can one chart the possibilities and limitations for intertextual progress within particular hegemonies and states of hegemonic struggle, one can also conceptualise intertextual processes and processes of contesting and restructuring orders of discourse (Fairclough, 1992, p. 103).
}

Fairclough drew upon a 'distinction used by French discourse analysts: "manifest" as opposed to "constitutive" intertextuality' (1992, p. 104 *citing* Authier-Révuz, 1982 
and Maingueneau, 1987). Fairclough renamed 'constitutive intertextuality' 'interdiscursivity' because it refers to 'the configuration of discourse conventions' that go into the production of texts (Fairclough, 1992, p. 104). Manifest intertextuality - with which this article is primarily concerned - refers, on the other hand, to other texts being 'explicitly present in the text under analysis' (Fairclough, 1992, p. 104). Table 1 summarises Fairclough's initial conceptual categories for analysing what was then referred to as manifest intertextuality. We shall see, though, that these categories retained some of the ambiguity we have seen in Kristeva and that Fairclough's later work on intertextuality (2003) began to recognise and address these ambiguities further.

\section{TABLE 1 ABOUT HERE}

If manifest intertextuality is to be understood as reference to specific other texts, as we have seen, then three of the categories in table 1 are problematic: presupposition, negation and meta-discourse. 'Presupposition' is problematic because it does not refer to a specific other text but to a memory or an understanding which, it can be inferred, might be shared amongst a social group. The origin may well have been a specific other text but reference to that text is absent. Similarly, as a form of presupposition, 'negation' is problematic for the same reason. These can both be important features of texts but, as we shall see below, they are better conceived as a form of assumption than manifest intertextuality. 'Meta-discourse' is also an important feature of some texts but it too is not a form of manifest intertextuality because it refers to itself not to a specific other text - it is a sort of 'intra-textuality'. In each of these problematic cases, important textual features are conflated with manifest intertextuality.

Fairclough's second major framework (2003) for analysing intertextuality, however, began to recognise and address these issues. 'Intertextuality' came to stand for 
'the presence of actual elements of other texts within a text - quotations' (Fairclough, 2003: 39) and 'presupposition' was reconceived as a form of 'assumption' which, instead of being intertextuality proper, was seen as another form of discursive link: dialogicality (Fairclough: 2003: 40). This refinement also began to recognise 'absence' as salient to an intertextual analysis: 'a significant initial question is: which texts and voices are included, which are exclude, and what significant absences are there?' (Fairclough, 2003: 47). These are useful refinements but the focus of intertextual analysis remained on quotation and reports of speech acts which both emphasise the form and content of texts rather than the patterns of intertextuality that appear across social practices and orders of discourse and by which hegemony potentially operates.

\section{TABLE 2 HERE}

Table 2 summarises the development of disambiguation described above. It demonstrates that what had been coined as 'intertextuality' by Kristeva developed into three related but distinguishable concepts: intertextuality, assumption and interdiscursivity. There is a potentially confusing shift in terminology in which ‘intertextuality' has been a broad category (Kristeva), a broad category with two subsets (manifest intertextuality and interdiscursivity in Fairclough, 1992) and the narrower category of Fairclough, 2003. Further, in 2003, Fairclough no longer used 'intertextuality' in the broader sense. It is this latter sense of intertextuality that I use in the reminder of this article: intertextuality refers to the linkage of one text to specific other texts by means of it incorporating some element of, or referent to, those other texts. The related, and perhaps more conceptually difficult categories 'assumption' and 'interdiscursivity’ require more conceptual rethinking which is beyond the scope of the present article. 


\section{Conceptual Absence in Intertextuality}

My work suggests that to map intertextuality as an element of orders of discourse we need to account for the relational function of intertextuality - as well as the formal appearance of intertextual reference - at each stage in the research design: research aim, the method of data collection, and method of data analysis. There are two areas for development. First, we must have a conceptual framework which emphasises the network that that intertextuality creates as the unit of analysis. Such a framework includes, as I show in the following section, four key concepts which focus the research design on the relational function of intertextual networks: inter-text, network of intertexts, networks of social practices and typicality. It includes principled methodological choices for developing a body of data for intertextual analysis: starting from events, text-types or social practices. It also includes meta-data on texts and their origins that are crucial for mapping which elements of social formations and practices are brought into an intertextual relation: origins and originators of texts, text-type, and named texts. This approach, I suggest, puts CDA in a position to comment on what is typical in the uses of intertextuality for a social practice or network of practices.

To be clear, this approach raises questions of research design and the resources available for intertextual research. An analysis of texts produced during the course of a single event may be very easily manageable. Figure 1, below, shows a rudimentary analysis of three intertexts referred to in the 'release' by a UK government department to the press. An analysis starting from text-types, or from a social practice is likely to require more data and greater analytical resource. Section 6 , below, elaborates on some of the implications for research design.

There are also ways that we can supplement our understanding and capacity to analyse the use of intertextuality within texts. Until now, our conceptualisation of intertextuality has tended to focus upon the intertextual incorporation of parts of texts - 
direct or indirect quotes or implied reference to some portion of a prior or subsequent text. My research, however, is showing that a very significant part of intertextuality is the reference to whole texts - through the titles or names of texts, and generic reference to kinds of text. I discuss the analysis of intertextual reference to whole texts below.

Second, until now, our conceptualisation of intertextuality has also tended to focus upon the presence of intertextuality and has under emphasised the absence of intertextuality. Again, my research is showing that a very significant part of intertextuality is absence thereof: texts and sources of texts have that are not brought into intertextual relations either at crucial moments during events or routinely as a convention of a social practice. Intertextuality as a means of mapping orders of discourse must account for significant absences in the way I show below. Finally, I revise the primary focus for the analysis of parts of text to quotation and reporting phrases.

\section{Analysing Manifest Intertextuality in Discourses and Orders of Discourse: Key Concepts}

In the following sections I present key concepts for the systematic analysis of intertextuality and illustrate these with examples from the transcript of a speech given in 2015 by the then UK secretary of state for Energy and Climate change, Amber Rudd which appeared on the Department for Energy and Climate Change website. I also refer to a press release from that department which announced some of the details of this speech. In this paper, I limit the presentation to illustrative examples. A full analysis will appear in due course.

First, I refer to texts that are brought into an intertextual relation with each other by means of manifest intertextual reference as 'text' (for the referring text) and 'inter- 
text' for the text referred to. This brings the advantage of giving a simplified naming convention to the relation and the texts in that relation. For example:

\author{
As the former Chief Scientist at DECC, David Mackay, said: "If everyone does a \\ little, we'll achieve only a little. We must do a lot. What's required are big \\ changes." (Rudd, 2015)
}

\begin{abstract}
Amber Rudd's speech (text) makes David Mackay's book (as it turns out) one of its inter-texts. As we shall see in the following sections, the speech has other inter-texts and, to be sure MacKay's book also has inter-texts of its own. Using this terminology, I shall go on to present the three key concepts: networks of inter-texts; the intertextual networking of social practices; typicality in intertextuality.
\end{abstract}

\title{
Networks of inter-texts
}

The first way of conceptualising inter-texts, and the potential for intertextual analysis, is at the level of societal events. Analysis of the production of texts during an event could show their intertextual relations with each other or with texts in linked events from within and beyond the social practice concerned. A network of inter-texts is the groups of texts that connected to each other through intertextuality; it includes the preceding and anticipated texts that appear in the texts associated with a specific event. As we shall discuss below, in empirical CDA this requires further detailed methodological consideration to determine the scope and starting point for analysis. Figure 1 illustrates the immediate network of inter-texts of the press release: the speech of Amber Rudd is an inter-text of this press release issued by DECC (New direction for UK energy policy, 2015); the intertextual relation is manifest in the phrases: "Energy and Climate Change Secretary Amber Rudd has set out her vision..." and "Speaking at the Institution of Civil Engineers in London today". The press release also refers to an anticipated Paris Conference agreement and a Spring Consultation. 


\section{FIGURE 1 ABOUT HERE}

\section{Networks of social formations and practices}

Intertextual reference brings diverse events, social formations and social practices into a relationship with the text and its social practice. This observation recognises that texts are produced in different social practices and different formations. This is important because different social formations are likely to have different procedures and conventions for producing texts and, therefore, intertextual reference entails a degree of recontextualisation: there are likely to be principles which select and deselect, emphasise and deemphasise and frame aspects of texts differently to those in the source practice. An intertextual relation gives voice (however it is then used) to some social practices and not to others; further, various other practices may lend degrees of authority, and access to knowledge claims, which would not otherwise be available to the practice at hand. For example, political practice may form an intertextual relation with practices of academic, scientific research, statistical work from the official office of statistics and to the evidence gathering of a parliamentary committee through reference to the findings of such research. Indeed, Rudd's speech makes these connections and more, but not to texts which would form a link to the lifeworld texts of citizens, or environmental campaigning, for example.

\section{Typicality}

This brings us to a further crucial concept - typicality. An intertextual analysis ought to be able to address the general research question: what patterns of intertextuality are typical for a social practice? To establish typicality analysis needs to go beyond texts produced during a limited set of social events. For typicality, the units of analysis 
are the social formation or the social practice; for an intertextual analysis, the focus is on the networks of inter-texts within and between social formations and social practices.

Networks of inter-texts:

- specific texts that are typically referred to

- text-types that are typically referred to

Networks of social formations and practices:

- social formations that are typically a source of inter-texts

- social practices that are typically a source of inter-texts

Typicality embeds a core distinction in CDA between text and discourse: 'typical' implies the likelihood of 'untypical' instances: typicality at the discursive level does not imply that all texts conform to that pattern. In our current example, a full analysis might look at each of the ministerial speeches and given by Rudd to establish how typical this speech is for her use of intertextuality. These concepts, inter-texts; networks of intertexts and networks of social formations and practices lay the foundations for critical analysis and interpretation.

\section{Building a Corpus for Analysing Manifest Intertextuality in Discourses and Orders of Discourse}

The concepts discussed above give rise to questions of gathering and expanding upon a set of data: to accommodate typicality in our analysis of intertextuality we need, as indicated above, a corpus of texts which is extensive enough that we can use it to make confident claims about social formations and social practices. In some cases, a research project may require an approach which employs a sampling method - much quantitative work and in some approaches associated with CDA - such as corpus linguistics - do this. However, for other research projects, in some fields of social 
practice there is an approach to the systematic analysis of intertextuality that does not rely on the sampling of texts; instead, we can limit the intertextual analysis to an aspect of the social formation or practice and adjust our claims accordingly. In the following sections, I present methods of expending the corpus for an intertextual analysis: first, around social events; second, around social practices.

\section{Building on Events}

In some cases, we can delimit our analysis by the text produced in specific social practices and formations around a specific event. Such an approach may enable us to make confident claims about intertextuality that reach to all the available texts in an intertextual chain or about text types around a specific event. In the case of an intertextual chain, we can expand our corpus of texts by following the manifest intertextual references and gather the inter-texts. Here, we start from a single text and build our corpus from the inter-texts that it yields in manifest intertextual reference. Second, we can gather texts around a set of events and then carry out an intertextual analysis. For instance, in parliamentary practices, we can analyse speeches made in the house of commons chamber in debates on the passage of a piece of legislation. [Author] (forthcoming, for example) deals with the passage of the legislation which enabled a transferal of the British Gas Corporation from public to private ownership. Subsequent work could analyse intertextuality in the available texts on this event from specific social practices: other texts from parliamentary practice or the social practice of national mass media reporting, for example.

\section{Building on Social Practices}

A more direct route to the analysis of social formations and practices as a unit of analysis is to build out a corpus based on text-types that are typical of those formations 
or practices. Once we have established the social formation or practice that we take as our unit of analysis, we can then begin to establish the text-types produced in that practice. Of these text-types, we can take one type and gather instances of that text-type. In research on government, for example, we could take all the press releases that are produced by a government department and if we further delimit our corpus by year or period we can analyse patterns of intertextuality and make claims for what the typical intertextual habits are for the production of press releases in that department over that period (for example, for the UK's DECC there we're 13 press releases in 2016, 45 in 2015). The ambition then would be to expand on that delineation: a methodological choice may be over other text-types in that department and period; the same text-type in that department in other periods; the same text-type in other departments in the same period.

We have seen, then, two methods for building and extending a corpus of texts for intertextual analysis and a tool for handling the quantity and type of data analysis that an intertextual analysis requires if we want to make the most of CDA's potential to understand and critique intertextuality as an indicator of orders of discourse and as an important aspect of social formations and social practices. We saw that we can build by expanding on specific events and that we can build a corpus by focussing on text-types within a limited aspect of social practices. Each of these I see as enabling a modular approach to the analysis of intertextuality: there can be important and worthwhile critiques of those aspects of social formations discussed in the examples given but we should also see the analysis of intertextuality in CDA as an ongoing project which reaches beyond single research projects and single researchers or teams. This general question could be operationalised, for example in: 
- comparative analyse of the discursive tendencies of intertextuality across different social formations and practices within the same social bloc for tracing potential alternative practices

- comparative analyse of the discursive tendencies of intertextuality across different temporal periods for tracing social change

- analysis of text versus discourse in the same social bloc

\section{Meta-Data}

To effectively chart textual and discursive relations between aspects of social formations and social practices, and therefore hegemonies and processes of restructuring orders of discourse, an intertextual analysis must be able to show which aspects of social practices - beyond the content of texts - are linked together and how. To do this, we must gather 'meta-data' on inter-texts and make it a focus of our analysis Let us look in more detail at an intertextual reference in the DECC press release, for example:

$$
\begin{aligned}
& \text { Speaking at the Institution of Civil Engineers in London today the Energy } \\
& \text { Secretary revealed her policy priorities and her strategy for putting them into } \\
& \text { action. (New direction for UK energy policy, 2015) }
\end{aligned}
$$

We could say that this is indirect discourse and begin to question the emphasis that this gives to some aspects of the speech over others and we might also want to check the accuracy of this reformulation. We can, however, say much more about the aspects of social practices that this reference links together intertextually. It refers to another text produced as part of the activities of DECC: to a speech, given by a Minister at a named place in London. It aims to forge a link between this speech and practices of press reporting. The intertextuality links a minister and her speech to the production of a press release in her department and, potentially, to the press. We could now go on to ask if 
this is typical or not of intertextuality in this department; is this typical of the discourse of DECC and typical of the order of discourse which holds between DECC and the press?

To formalise this more clearly, we can identify general types of metadata - data about the texts that we are using as data - for analysis of intertextuality: text origins and originators; text name; text-type and, crucially, absences that the metadata might indicate. First, the origins of inter-texts. This is crucial for understanding the networking function of inter-texts as a means of connecting social practices and elements of social practices. The meta-data for each text and inter-text that we are analysing ought to include, in each case, a name for the social practice within which it was produced. A question for the research design of an empirical CDA project focussed on intertextuality is the naming scheme for the social practices which serve as origins for texts. Once we have done so, we can begin to chart the intertextual links that are drawn within and between social practices.

\section{Social origins of text producers}

Second, and dependent on research aims, we can analyse the social origins of the producers of the inter-texts. The meta-data one would seek depends on the question under investigation but could include:

- Gender

- Class

- Institution

- Affiliation (political, religious)

- Geography

This is not intended to be an exhaustive list but it does indicate the potential for 
intertextual analysis to be used in a wide range of research. In the example above we could investigate questions of gender and class - we might expect that a department refers to texts delivered by its minister but is the quantity and quality of how departments do this affected by the gender or social class of its minister, for example? We could also follow up on the reference to the 'Institution of Civil Engineers in London' - are speeches given in particular institutional settings or geographical locations given more intertextual prominence than others, or not? If so why so?

\section{Text-types as inter-texts}

Third, identifying text-types - such as the speech in the example above - as part of the meta-data for our analysis of intertextuality is crucial for mapping which elements of social practices are being linked together textually or discursively. Are there some text-types that are more likely to be inter-texts than others? An analysis of texttypes as in intertextuality may also give a map of how 'closed' or 'open' a text-type or practice is to a variety of text-types - academic articles are likely, for example, to refer mainly to other academic articles or books than to other text-types. Some kinds of texttype are so prominent and relatively formalised within or across social practices that the type is widely known and has a generic name: news report, academic essay, political speech, as examples. On the other hand, it may be the case that a text-type is less well defined, in which case analysis may have to approximate a type. The fact that some text-types have these names may be an important element of analysis and interpretation in intertextuality are the ready named types more likely than other less well-defined types to become inter-texts? 
Named Texts

Third, text name. For some text-types, it is common practice for the text producer to name their text. Naming practices can be significant for intertextual analysis in three ways:

(1) Some texts may become prominent in a set of events or in social practice, becoming a common reference point, for example, or taking on a status that becomes a focus point

(2) As we saw in Fairclough, meta-language can be an important indicator of control, so named texts may be an indicator that they are considered are important

(3) A text may become 'named' not as part of its production but in subsequent texts, and this might be an indicator of inter-texts elevating the status of an anterior text

For an intertextual analysis being able to trace the specific texts that are often named during a course of events and being able to see the influences that they have at specific points during that course of events is an advantage. Similarly, a text may be named so often in a social formation or practice that it becomes a feature of that social practice or social formation.

Finally, on meta-data, the identification of absence is a crucial part of the analysis of metadata. We can analyse absences for each and all categories of meta-data: the origins of texts, text-types, and named texts. For this kind of analysis there are two analytical processes available: first, comparison of one analytical unit with at least one other analytical unit; second, analysis of an analytical unit against a theoretically plausible inventory of what could be included. In the first case, we might compare the metadata of our texts with those produced in a different social practice, different time 
periods, or from different locations. Again, careful methodological consideration ought to be given to this during the research design stage of an intertextual project. In the second case, we might look to our meta-data categories and, through interdisciplinary work or careful literature review of work from other scientific and social scientific disciplines, derive a list of categories that are shown to be important. Is there an absence of women as a source of inter-texts in a practice, for example? Are there important practices that are simply ignored - significant social scientific research articles on topics being debated in parliament, for example?

\section{Analysing the incorporation of inter-texts in texts}

The meta-data shows what is brought into an intertextual relation; but we can also chart how inter-texts of different origin, text-type or name tend to be incorporated in texts at various points in a social practice or network of social practices. First, though, we must supplement our conception of what counts as intertextual reference. As we saw, above, Fairclough gives a framework for the analysis of the presence of intertextuality and clear guidance on how these might be open to critical interpretation. We can supplement those categories with additional analytical categories and interpretive tools which distinguish reference of parts of text (as in Fairclough), whole texts, ambiguity and absence. Table 3 shows the analytical categories by which we can identify salient textual cues to the incorporation of inter-texts in the text under analysis. These categories are not mutually exclusive; many of these elements may be combined in a single incorporation of an inter-text. Indeed, as my examples show, it appears to be a normal feature of intertextual reference to combine textual cues to frame an intertextual reference. As I show, it is the combination of the Fairclough categories, my supplementary categories, and the meta-data categories I gave above that set the 
foundation for CDA to fulfil the potential in intertextuality to chart networks of intertexts.

\section{TABLE 3 HERE}

\section{Parts of Texts}

Reference to parts of texts emphasises some aspect of that text and deemphasises, or excludes others: it is for the analyst to evaluate the significance of this emphasis/de-emphasis. My focus is on quotation and 'reporting phrases', rather than direct and indirect discourse (though an analyst may use these terms additionally). Marking parts of texts as 'quotation', or not, effectively gives us the same information as identifying direct and indirect discourse. More importantly, it is the 'reporting phrases' (verb phrases, adverbial phrases and some evaluative noun or adjectival phrases) which establish the relation-type between text and inter-text.

\section{Quotation}

In the examples given in table 3, Rudd's speech (2015) emphasises the words of Mackay but creates an intertextual relation to his appeal for 'big changes' rather than to any factual propositions or knowledge claims that he may have made.

\section{Reporting phrases}

The verb phrases 'said' and 'has said', in the two examples appear to give a neutral framing to this inter-text, but the adverbial phrases 'as the former Chief Scientist at DECC *said*' and 'as the committee on climate change *has said* - along with the evaluation 'it's clear' - create an agreement-relation between Rudd's speech and the two inter-texts. A full analysis could establish the typicality of these intertextual relations. 


\section{Whole Texts}

Reference to whole texts is also an essential part of intertextuality. First, specific texts can be named. Naming a text emphasises that text and if there is no other form of intertextual reference, referring to a text by name de-emphasises its content. These are relatively clear functions of this kind of intertextuality. There are other potential meanings for named-text intertextuality which require more interpretive work and which are more context dependent. Naming can be:

- an acknowledgement of a source of information

- an attempt to bring in authority from the source

- a demonstration of how adept a speaker is with a field of knowledge

Second, a text may be framed as being an iconic text. Framing a text as 'iconic' is a matter of emphasising the significance of a text and, depending on how it is framed, may also be a way of attaching importance to a text, as in example 4 in table 3 . Third, a generalised reference to text-types is a form of manifest intertextuality. Again, unless this form is combined with another form of intertextuality, the content is deemphasised, and the meaning of the form itself takes precedence (see table 3, example 5). Finally, an intertextual reference to generic communicative acts (borrowing from the notion of speech acts) emphasises a general intent without specifying the form of a text (table 3, example 6).

\section{Ambiguity}

Ambiguity in texts can be a clue to interesting textual or discursive formulations; ambiguity is possible where it is unclear if a phrase refers to a text or something else. In the example text (table 3, example 7, and discussed above), 'Electricity Market Reform' looks like it is an inter-text: the transcription capitalises the 
initial letter of each word in this phrase. In British written English this kind of capitalisation of a phrase would conventionally indicate a proper noun, which can include the name of a document. 'Electricity Market Reform' does not look like the name of an organisation or person so one could assume that it is the name of a document. The surrounding text raises doubts, though - the usual convention would be to use the preposition 'in' when referring to a document: 'developed in Electricity Market Reform'; the preposition 'through' is usually more applicable to a process. Further investigation, of UK government web archives, find that Electricity Market Reform is the main title of at least four government documents and is also referred to both as a 'consultation' and 'a project' [https://www.gov.uk/government/consultations/electricity-market-reform]. In this case, investigation of textual ambiguity points to the nominalisation of a process.

\author{
Absences \\ We can undertake a potentially very useful analysis of important but less \\ obvious patterns of absence, presence, emphasis and de-emphasis in networks of inter- \\ texts using the framework that I have outlined in table 3 in combination with the \\ identification of meta-data described above. Table 4 gives examples of intertextual \\ reference from the Rudd speech which also appear to have important absences or de- \\ emphasis of the intertextual cue. Example 1 (table 4) shows there is an absence of overt \\ cues to intertextuality; examples 2-3 (table 4) have intertextual cues but they are cues \\ that do not make the source of the inter-text at all clear. In combination with analysis of \\ our meta-data categories it appears, in this speech, that Rudd eschews specific \\ intertextual reference to sources of expert knowledge (indeed, to any factual knowledge \\ claim) but emphasises specific intertextual reference to 'authority' figures who are \\ speaking (or writing) beyond (or at the very limits of) their specific expertise. This gives
}


rise to some important research questions: how typical is this pattern of intertextuality? Is it typical of this politician, of the office she holds as a minister, of politicians in Westminster, of recent periods of time?

\section{TABLE 4 HERE}

\section{Conclusion}

This article has developed and further disambiguated the methodological framework for intertextuality in CDA and made it more readily and meaningfully available as a tool for analysis. This enhanced framework makes CDAs conceptual and analytical framework for intertextual analysis far more congruent with its ambition to chart orders of discourse and their contribution to social formations, practices and networks of practice than has been the case until now. Adding concepts which specifically identify aspects of social practices that are being drawn on as inter-texts opens-up networks of inter-texts to analysis. Extending the analytical categories for intertextual reference beyond parts of texts to include whole texts gives a more complete view of intertextuality than we had before. Identifying ambiguity and absence also gives a more complete way of charting networks of inter-texts and a potentially powerful route into critique of networks of inter-texts. Typicality is key to moving the focus of intertextuality from specific texts - important as they are - to the level of discourse and orders of discourse. Opening-up discourse and orders of discourse to intertextual analysis enables CDA to address critical questions of social practices:

- Who/what typically produces the inter-texts used in a social practice?

- Who/what is not typically used as a source of inter-texts in a social practice?

- Is this pattern of inclusion-exclusion necessary or inevitable?

- Does it advantage some over others? 
Specifically, the rethinking of intertextuality presented in this article enhances CDAs critical power to analyse manifest intertextuality. CDA is now able to move toward addressing questions over intertextual tendencies at the levels of discourse and orders of discourse and to begin to show whether instances of intertextuality are typical for a practice or anomalous and unique. Metadata on inter-texts is crucial for analysis of the networking work that is done through intertextual reference; the specific metadata we gather ought to be refined to the research field under investigation. We can analyse patterns of typicality to consider deviations from the norm and specific uses of intertexts in a critical way. Crucially, analysis of what is incorporated and how it is incorporated must be balanced with an analysis of what is absent - both regarding the meta-data categories and regarding the modes of incorporation. This then is the basic framework for a systematic analysis of manifest intertextuality in CDA.

The conceptual development of intertextuality in the CDA literature has been one of disambiguation. First, it developed distinctions between texts, discourse and orders of discourse and recognised a correspondence of these with events, practices and networks of practice; the conceptualisation of intertextuality in CDA was further disambiguated so that is could be a means of establishing and inflecting discursive relations within and between events, practice and networks of practice. Next, CDA recognised and adopted a distinction between manifest intertextuality and interdiscursivity, which enabled analysts to see influence and interaction between diverse levels of text and discourse. These developments opened-up the potential to map discursive relations and processes of change within and between societal formations and practices. However, we have also seen that there a remarkable absence, in empirical CDA, of systematic studies which use intertextuality beyond the level of texts and events. In this article, I have disambiguated our concept of intertextuality further by 
presenting a framework through which, conceptually, CDA can employ an intertextual analysis to chart relations within and between practices and networks of practice. The next step is to develop practical techniques and procedures for executing this new framework. Further, and more ambitiously, there is a clear need to develop our analytical approach to interdiscursivity and dialogicality.

\section{References}

Authier-Révuz, J. (1982). Hétérogenéité montrée et hétérogenéité constitutive: éléments pour une approche de l'autre dans le discours. DRLAV, 32.

Bubikova-Moan, J. (2017). Constructing the multilingual child: The case of language education policy in Norway. Critical Discourse Studies, 14(1), 56-72.

Fairclough, N. (1992). Discourse and social change. Cambridge: Polity Press.

Fairclough, N. (2003). Analysing discourse: Textual analysis for social research. London: Routledge.

Jung-Wook Hong, J. (2012). 'Challenge' or 'collaboration' social interaction and recontextualization: McDonald's CSR report. Critical Discourse Studies, 9(2,) 149-162.

Kristeva, J. (1986). Word, Dialogue and Novel. In T. Moi (ed.), The Kristeva Reader (pp.35-61). Oxford: Blackwell.

Lassen, I. (2008). The Red Gold: analysing a nexus of practices. Critical Discourse Studies, 5(1), 1-19.

Maingueneau, D. (1987). Nouvelles Tendances en Analyse du Discours. Paris: Hachette.

New direction for UK energy policy (2015, November 18). Department of Energy and Climate Change. Retrieved from https://www.gov.uk/government/news/newdirection-for-uk-energy-policy

Oostendorp, M. (2014). The multimodal construction of the identity of politicians. Critical Discourse Studies, 12(1), 39-56.

Rudd, A. (2015, November 18) Amber Rudd's speech on a new direction for UK energy policy. Retrieved from https://www.gov.uk/government/speeches/amber-ruddsspeech-on-a-new-direction-for-uk-energy-policy 
Salama, A.H.Y. (2012). The rhetoric of collocational, intertextual and institutional pluralization in Obama's Cairo speech: A discourse-analytical approach. Critical Discourse Studies, 9(3), 211-229. 


\begin{tabular}{|c|c|c|c|}
\hline Form & Description & Example & Potential for critique \\
\hline $\begin{array}{l}\text { Discourse } \\
\text { representation: } \\
\text { direct } \\
\text { discourse }\end{array}$ & $\begin{array}{l}\text { A direct quote from } \\
\text { an anterior text }\end{array}$ & $\begin{array}{l}\text { Mrs Thatcher warned } \\
\text { Cabinet colleagues: "I will } \\
\text { not stand for any } \\
\text { backsliding now"' (cited in } \\
\text { Fairclough, 1992: 107) }\end{array}$ & \multirow{2}{*}{$\begin{array}{l}\text { The reporting verb } \\
\text { represents 'the nature of } \\
\text { the action performed' } \\
\text { and imposes 'an } \\
\text { interpretation upon the } \\
\text { represented discourse' } \\
\text { (Fairclough, 1992: 120) }\end{array}$} \\
\hline $\begin{array}{l}\text { Discourse } \\
\text { representation: } \\
\text { indirect } \\
\text { discourse }\end{array}$ & $\begin{array}{l}\text { The indirect } \\
\text { representation of } \\
\text { speech }\end{array}$ & $\begin{array}{l}\text { Mrs Thatcher warned } \\
\text { Cabinet colleagues that she } \\
\text { would not stand for any } \\
\text { backsliding then' (cited in } \\
\text { Fairclough, 1992: 107) }\end{array}$ & \\
\hline Presupposition & $\begin{array}{l}\text { Propositions which } \\
\text { are taken by the } \\
\text { producer of the text } \\
\text { as already } \\
\text { established or } \\
\text { "given"' (Fairclough, } \\
\text { 1992: 120) }\end{array}$ & $\begin{array}{l}\text { 'The Soviet threat is a myth' } \\
\text { presupposes that there is a } \\
\text { Soviet threat (Fairclough, } \\
\text { 1992: 120) }\end{array}$ & $\begin{array}{l}\text { Can 'postulate } \\
\text { interpreting subjects with } \\
\text { particular prior textual } \\
\text { experiences and } \\
\text { assumptions, and in so } \\
\text { doing they contribute to } \\
\text { the ideological } \\
\text { constitution of subjects' } \\
\text { (Fairclough, 1992: 121) }\end{array}$ \\
\hline Negation & $\begin{array}{l}\text { A denial which } \\
\text { presupposes the } \\
\text { proposition being } \\
\text { denied }\end{array}$ & $\begin{array}{l}\text { A newspaper headline in } \\
\text { The Sun reads "I Didn't } \\
\text { Murder Squealer! Robbey } \\
\text { Trial Man Hits Out" } \\
\text { (Fairclough, 1992: 121), } \\
\text { presupposes an anterior } \\
\text { text in which someone } \\
\text { made the claim that the } \\
\text { 'Robbey Trail Man' had } \\
\text { committed such a murder }\end{array}$ & $\begin{array}{l}\text { 'are often used for } \\
\text { polemical purposes' } \\
\text { (Fairclough, 1992: 121) } \\
\text { by 'incorporating other } \\
\text { texts only in order to } \\
\text { contest and reject them } \\
\text { (Fairclough, 1992: 122) }\end{array}$ \\
\hline $\begin{array}{l}\text { Meta- } \\
\text { discourse }\end{array}$ & $\begin{array}{l}\text { Elements of a text in } \\
\text { which it refers to itself }\end{array}$ & $\begin{array}{l}\text { 'he was sort of } \\
\text { paternalistic'; 'as x might } \\
\text { have put it'; 'in scientific } \\
\text { terms'; 'metaphorically } \\
\text { speaking' (Fairclough, } \\
\text { 1992: 122) }\end{array}$ & $\begin{array}{l}\text { Can give 'the illusion' of } \\
\text { control over discourse; } \\
\text { apparently 'innocent } \\
\text { clarification of meaning' } \\
\text { in metadiscourse may } \\
\text { be an effort to redefine a } \\
\text { concept for ideological } \\
\text { purposes (Fairclough, } \\
\text { 1992: 123). }\end{array}$ \\
\hline
\end{tabular}




\begin{tabular}{|l|l|l|l|}
\hline Irony & $\begin{array}{l}\text { A statement which } \\
\text { echoes another } \\
\text { utterance but with an } \\
\text { alternative meaning }\end{array}$ & $\begin{array}{l}\text { "For example, suppose you } \\
\text { say 'It's a lovely day for a } \\
\text { picnic'. We go for a picnic, } \\
\text { it rains, and I then say 'It's } \\
\text { a lovely day for a picnic'. } \\
\text { My utterance would be } \\
\text { ironic" (Fairclough, 1992: } \\
\text { 123) }\end{array}$ & $\begin{array}{l}\text { The purpose of irony is } \\
\text { to expative attitude' } \\
\text { utterance. (Fairclough, } \\
\text { 1992: 123). }\end{array}$ \\
& & & \\
\hline
\end{tabular}

Table 1: Summary of Fairclough's (1992) Typology of Intertextuality 


\begin{tabular}{|c|c|c|c|}
\hline Kristeva & \multicolumn{3}{|c|}{$\begin{array}{l}\text { Intertextuality } \\
\text { Both reference to specific other texts, and a more general response } \\
\text { and interaction with a body of literature and literary structures }\end{array}$} \\
\hline \multirow[b]{2}{*}{$\begin{array}{l}\text { Fairclough } \\
1992\end{array}$} & \multicolumn{3}{|c|}{$\begin{array}{l}\text { Intertextuality as an overarching term as in Kristeva but which } \\
\text { also has the two subcategories: }\end{array}$} \\
\hline & \multicolumn{2}{|c|}{$\begin{array}{l}\text { Manifest intertextuality } \\
\text { Other texts explicitly present and } \\
\text { incorporation of other texts without } \\
\text { explicit reference }\end{array}$} & $\begin{array}{l}\text { Interdiscursivity } \\
\text { 'The configuration of } \\
\text { discourse conventions' } \\
\text { present in texts (1992: 104) }\end{array}$ \\
\hline $\begin{array}{l}\text { Fairclough } \\
2003\end{array}$ & $\begin{array}{l}\text { Intertextuality } \\
\text { 'the presence of } \\
\text { actual elements } \\
\text { of other texts } \\
\text { within a text' } \\
(2003: 39)\end{array}$ & $\begin{array}{l}\text { Assumption } \\
\text { A connection } \\
\text { between one } \\
\text { text and others } \\
\text { which is 'not } \\
\text { generally } \\
\text { attributed or } \\
\text { attributable to } \\
\text { specific texts' } \\
(2003: 40)\end{array}$ & $\begin{array}{l}\text { Interdiscursivity } \\
\text { The 'particular mix of } \\
\text { genres, of discourses, and of } \\
\text { styles upon which [a text] } \\
\text { draws' (2003: 218). }\end{array}$ \\
\hline
\end{tabular}

Table 2: Summary of the development of the disambiguation of intertextuality 


\begin{tabular}{|c|c|c|c|}
\hline \multicolumn{2}{|c|}{ Example } & \multicolumn{2}{|l|}{ Type } \\
\hline 1 & $\begin{array}{l}\text { As the former Chief Scientist at DECC, } \\
\text { David Mackay, said: "If everyone does a } \\
\text { little, we'll achieve only a little. We must } \\
\text { do a lot. What's required are big } \\
\text { changes". }\end{array}$ & Quotation & \multirow[t]{2}{*}{ Parts of texts } \\
\hline 2 & $\begin{array}{l}\text { But it's clear, as the Committee on } \\
\text { Climate Change has said, that the fourth } \\
\text { carbon budget is going to be tough to } \\
\text { achieve. }\end{array}$ & Reporting phrases & \\
\hline 3 & $\begin{array}{l}\text { There's a picture from the Government art } \\
\text { collection that hangs in the Department of } \\
\text { Energy and Climate Change. It's called } \\
\text { "At the Coal Face" by Nicholas Evans. }\end{array}$ & Named texts & \multirow{5}{*}{ Whole texts } \\
\hline 4 & $\begin{array}{l}\text { In his seminal speech in } 1982, \text { he defined } \\
\text { the Government's role as setting a } \\
\text { framework that would ensure the market, } \\
\text { rather than the state, provided secure, } \\
\text { cost-efficient energy. }\end{array}$ & Iconic Reference & \\
\hline 5 & $\begin{array}{l}\text { I will shortly be launching a paper setting } \\
\text { out some of the possibilities and we will } \\
\text { consult formally in the spring to allow } \\
\text { action in the autumn. }\end{array}$ & Generic Text-type & \\
\hline 6 & $\begin{array}{l}\text { Paris must deliver a clear signal that the } \\
\text { future is low carbon that unleashes the } \\
\text { levels of private investment and local } \\
\text { action needed. }\end{array}$ & $\begin{array}{l}\text { Generic } \\
\text { Communicative Act }\end{array}$ & \\
\hline 7 & $\begin{array}{l}\text { We need a course correction using the } \\
\text { tools we have already developed through } \\
\text { Electricity Market Reform }\end{array}$ & Ambiguity & \\
\hline
\end{tabular}

Table 3: Intertextual Reference Types in Rudd (2015) 


\begin{tabular}{|c|c|c|c|}
\hline \multicolumn{2}{|c|}{ Example } & \multirow{2}{*}{$\begin{array}{l}\text { Absent } \\
\text { Intertextual } \\
\text { Reference Types } \\
\\
\text { Quotation/text- } \\
\text { type/origin }\end{array}$} & \multirow{2}{*}{$\begin{array}{l}\text { Comment } \\
\text { Presumably, this is not research } \\
\text { carried out by Rudd herself; the } \\
\text { source and detail of this } \\
\text { information is absent }\end{array}$} \\
\hline 1 & $\begin{array}{l}\text { Indeed a higher } \\
\text { proportion of our } \\
\text { electricity came from } \\
\text { coal in } 2014 \text { that in } \\
1999\end{array}$ & & \\
\hline 2 & $\begin{array}{l}\text { As the former Chief } \\
\text { Scientist at DECC, } \\
\text { David McKay, said: } \\
\text { Identification of } \\
\text { Absence } \\
\text { "If everyone does a } \\
\text { little, we'll achieve only } \\
\text { a little. We must do a } \\
\text { lot. What's required are } \\
\text { big changes." }\end{array}$ & Text-type & $\begin{array}{l}\text { We are not given the text-type of } \\
\text { this quote (a book), but more } \\
\text { importantly, this does not refer to } \\
\text { scientific knowledge which is the } \\
\text { domain of expertise of this man }\end{array}$ \\
\hline 3 & $\begin{array}{l}\text { The industry tells us } \\
\text { they can meet that } \\
\text { challenge, and we will } \\
\text { hold them to it }\end{array}$ & $\begin{array}{l}\text { Quotation/text- } \\
\text { type }\end{array}$ & $\begin{array}{l}\text { We are not given the source; is it } \\
\text { a hope or a commitment? Did } \\
\text { the entire industry endorse this } \\
\text { claim? }\end{array}$ \\
\hline 4 & $\begin{array}{l}\text { We know competition } \\
\text { works. It keeps costs } \\
\text { low and can deliver a } \\
\text { clean and reliable } \\
\text { energy system }\end{array}$ & $\begin{array}{l}\text { Quotation/text- } \\
\text { type/origin }\end{array}$ & $\begin{array}{l}\text { What is the source of this } \\
\text { knowledge claim? ONS statistics } \\
\text { show that consumer prices, for } \\
\text { example, have risen steadily and } \\
\text { consistently since competition } \\
\text { and now stand at } 150 \% \text { of the } \\
\text { pre-privatisation average }\end{array}$ \\
\hline
\end{tabular}

Table 4: Absences of intertextual reference cues in Rudd (2015) 


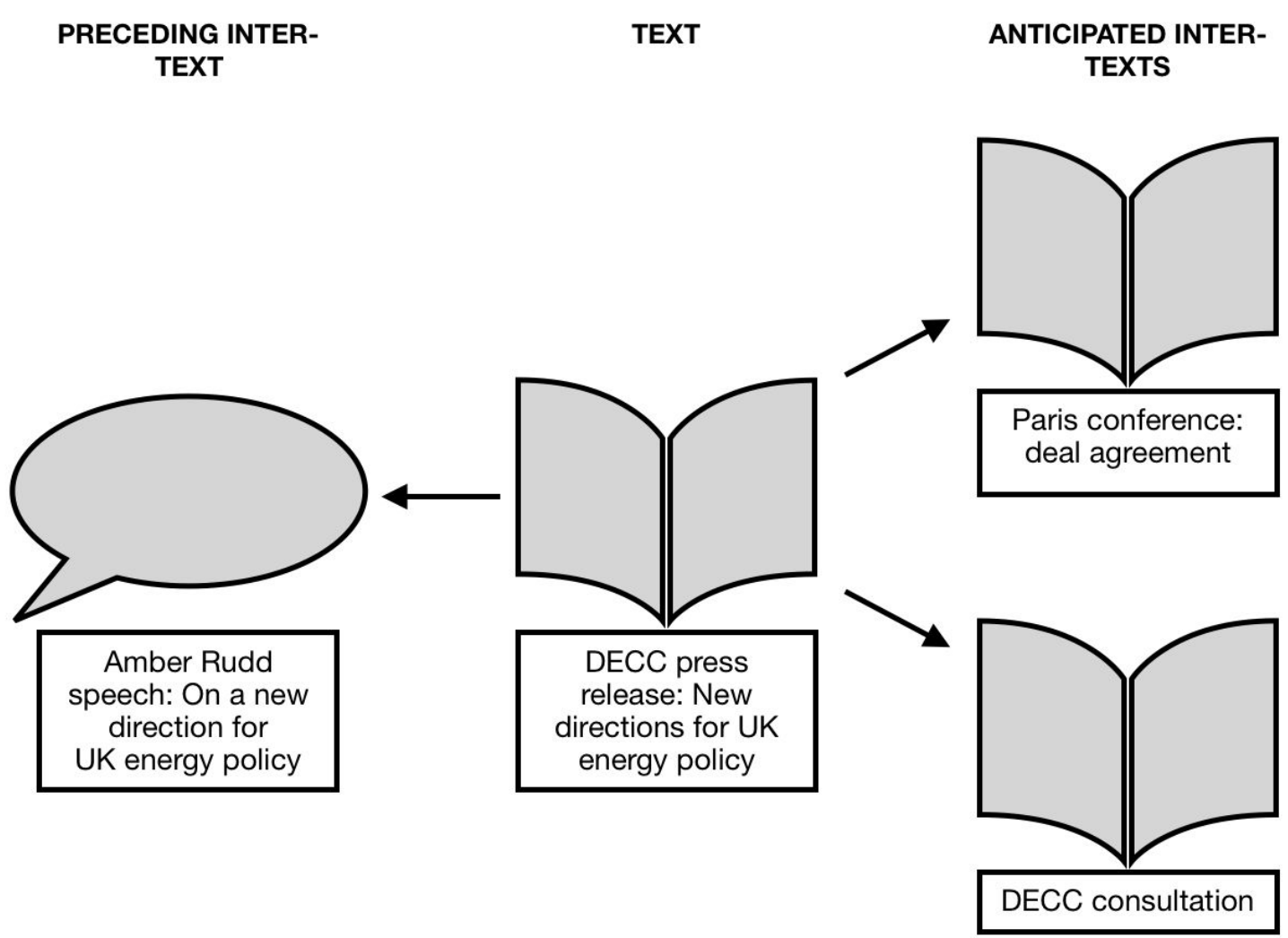
TEXTS

Figure 1: The network of text and inter-texts for the DECC press release, New directions for UK energy policy 


\section{Rethinking Intertextuality in CDA - response to reviewers}

I thank the reviewers for their very positive response to the article and am pleased that reviewer 2 recommends publication almost as the submission stood. I have made the minor corrections suggested by the reviewers:

- corrected example 7 in table 2 (now table 3)

- altered the phrasing from "p.1 "Intertextuality - instances of texts referring to other texts" to "Intertextuality - instances of texts linking to other texts (explicitly, implicitly, by referring to them or incorporating elements of them)" (reviewer 2). - Altered 'dialogue' to 'assumption' on response to reviewer 2's question which points out an error in the original submission.

Reviewer 1 invited me to consider two further points: first, on the potential size of the task in analysing absences and, second, on linking the article back to interdiscursivity. Both points anticipate current and future developments on the issues raised in the article and both reviewers clearly sees where the line of thinking put forward in the article might lead.

On the size of the analytical task, I am currently working through analytical techniques that facilitate working with such sets of data, which as reviewer 1 rightly suggests can become large (I stress 'can') using computer software. I've considered carefully the possibility of previewing this methodological work in the current article but believe that it does need an article or chapter (at least) of its own. However, I would also point out that the article already considers the issue of the size of the data set and various approaches to it in section 6. I've altered this section to make these considerations more prominent:

1. 'events' can be a site of analysis - the text or texts produced during an event can be analysed for inter-texts referred to in those texts and this can be a fairly small analytical task (as illustrated by the number of intertexts shown in the figure 1). I've added wording to this effect in section 4.

2. Section 6 discusses sampling as per corpus linguistics as one answer to the question raised, and another answer to limit the remit of the research - there's the example of looking at press releases from a specific government department in a single year - this needn't be too enormous and I've added the following to illustrate this: 'for the UK's DECC there we're 13 press releases in 2016, 45 in 2015'.

3. I've also refined 'research elsewhere' to refer to 'through interdisciplinary work or careful literature review of work from other scientific and social scientific disciplines'.

On the link back to interdiscursivity: again, this anticipates my own line of thinking on where this work will lead. In the case of interdiscursivity this is work is further down the line for me and not something l've paid close attention as yet. That being the case, I'm very keen that the article doesn't 're-ambiguate' intertextuality by including some part thought-out ideas on interdiscursivity. Instead, I've made the distinction between intertextuality, interdiscursivity and assumption more clear by adding a new table (2) and some text below it in section 3 which emphasises more clearly that the framework presented in the article is concerned only with intertextuality understood as texts incorporating elements of specific other texts.

There are some other minor corrections and adjustments that take account of the 
changes described above. 